\title{
Pengembangan Desain Pembelajaran Geografi dengan Pendekatan Konstruktivistik
}

\author{
Syaiful Khafid ${ }^{1 *}$ \\ ${ }^{1}$ Dinas Pendidikan, Jawa Timur, Indonesia
}

\section{A R T I C L E I N F 0 \\ Article history: \\ Received 8 April 2019 \\ Accepted 28 Juni 2019 \\ Available online 30 Juni 2019}

\author{
Kata Kunci: \\ Desain Pembelajaran; \\ Pembelajaran Geografi; \\ Pendekatan \\ Konstruktivistik \\ Keywords: \\ Learning Design; \\ Geography Instruction; \\ Constructivist Approach
}

\begin{abstract}
A B S T R A K
Tujuan penelitian pengembangan ini untuk menghasilkan desain pembelajaran geografi dengan pendekatan konstruktivistik meliputi: (1) model desain pembelajaran konstruktivistik (DPK), (2) rencana pelaksanaan pembelajaran (RPP), (3) bahan ajar geografi (BAG), (4) lembar kegiatan siswa (LKS), dan (5) lembar evaluasi belajar (LEB). Model penelitian pengembangan yang digunakan ialah R2D2, yaitu rekursif, desain, dan pengembangan. Model R2D2 memiliki tiga fokus yakni: (1) penetapan, (2) desain dan pengembangan, dan (3) desiminasi. Revisi model DPK di antaranya (1) ditambah uraian filsafat konstruktivisme dan filsafat pembelajaran konstruktivistik, dan (2) sintaks model DPK diadopsi dari model CLD Gagnon dan Collay. Revisi RPP antara lain: (1) dilengkapi lembar observasi aspek spiritual dan sosial, (2) skenario di RPP dibuat secara realistik, dan (3) tes uraian disertai kisi-kisi soal dan penskoran. Uji coba pembelajaran konstruktivistik berdasarkan hasil observasi aktivitas guru dan siswa di SMAN 1 Sidayu masing-masing
\end{abstract} mencapai 86,67\%, sedangkan aktivitas guru di SMAN 1 Kebomas mencapai 100\% dan aktivitas siswa mencapai $86,67 \%$. Supaya proses dan hasil mencapai optimal, siswa harus menguasai prinsip belajar konstruktivistik dan peran guru sebagai motivator, fasilitator, dan konsultan. Perkembangan nilai tim dari 16 tim belajar sebanyak 14 tim belajar memperoleh rerata perkembangan nilai $\geq 25$ dengan predikat super dan 2 tim belajar mendapatkan nilai berkisar 20-24 dengan predikat hebat. Respon mayoritas siswa terhadap pembelajaran konstruktivistik adalah menyenangkan.

\begin{abstract}
A B S T R A C T
The development research is aimed at producing a geography instructional design using constructivist approach which includes (1) the model of constructivist learning design (DPK), (2) lesson plan (RPP), (3) geography teaching material (BAG), (4) student worksheet (LKS), and (5) learning evaluation sheet (LEB).The development research model used is R2D2 that are reflective, recursive, design, and development. R2D2 Model has three focuses: (1) define, (2) design and development, and (3) dissemination. The DPK model revisions are (1) add a description of the constructivism and constructivist learning philosophy, and (2) add the syntax of DPK model adopted from CLD model of Gagnon and Collay. RPP revisions are (1) add observation sheet of spiritual and social aspects, (2) scenario in RPP is made realistically, and (3) the description test along with problem lattice and scoring. Constructivist learning testing based on the observation of each of teachers' and students' activity at SMAN 1 Sidayu achieved 86.67\%, while teachers' activity at SMAN 1 Kebomas achieved 100\% and students' activity achieved 86.67\%. In order to achieve an optimal process and result, the students must master the principles of constructivist learning and the teachers' role as motivators, facilitators, and consultants. The team score development of 16 learning teams are 14 learning teams obtain the average development rate $\geq 25$ with excellent predicate and 2 learning teams obtain scores ranged 20-24 with great predicate. Responses of the majority of students on constructivist learning are pleasing.
\end{abstract}

* Corresponding author.
E-mail addresses: syaiful.khafid@yahoo.co.id 


\section{Pendahuluan}

Pendidikan Praktik pembelajaran di sekolah sebagian besar masih menggunakan pendekatan behavioristik, termasuk dalam hal pengembangan desain pembelajaran. Kualitas proses dan produk pembelajaran belum memadai, lebih-lebih kalau dikaitkan dengan upaya mempersiapkan manusia Indonesia di masa depan (Mustaji \& Sugiarso, 2005: 2). Manusia dituntut kritis, kreativitas, kolaborasi, saling pengertian lintas budaya, komunikasi, memakai komputer, karier dan belajar mempercayai diri sendiri (Ardhana, 2001: 6). Dalam konteks pembelajaran geografi, manusia juga dituntut berpikir dan bertindak geografis.

Demikian pula pola pembelajaran yang digunakan guru masih berorientasi pada penyampaian materi sebagai produk, belum pada cara mendapatkan ilmu sebagai proses (Mutohir, 2003:94; Ertmer \& Newby, 2013:48-50). Hal ini disebabkan kekurangmampuan guru dalam menyelenggarakan pembelajaran yang memenuhi tuntutan abad pengetahuan, sebagian lagi mungkin terjadi karena kesalahan cara pandang guru terhadap pembelajaran geografi di sekolah.

Pembelajaran geografi sebagian besar menggunakan desain pembelajaran dengan pendekatan behavioristik belum menekankan perspektif spasial (Khafid, 2007: 584). Strategi pembelajarannya memakai format penyampaian informasi, karena teori ini menganggap bahwa belajar ialah perolehan pengetahuan. Mengajar ialah memindahkan pengetahuan kepada siswa, belum menekankan aktivitas siswa membangun sendiri pengetahuannya (Mustaji \& Sugiarso, 2005: 2). Hasil pengawasan di sekolah, ternyata guru geografi masih tetap sebagai sumber belajar paling dominan, belum memanfaatkan sumber belajar yang beragam. Pembelajaran geografi sebagian berpusat pada kegiatan mendengar dan menghafal, belum mengarah pada kegiatan belajar aktif dan kreatif, artinya siswa membangun sendiri wawasan geografinya, bekerja, dan berpikir seperti seorang geograf.

Suatu kesalahan besar yang masih terdapat dalam pembelajaran geografi di sekolah adalah kurangnya penjabaran secara kontekstual dan operasional terhadap konsep-konsep geografi dengan pendekatan spasial, ekologikal, dan kompleks regional yang dikemukakan dalam bahan ajar atau buku paket, atau guru geografi ketika melaksanakan pembelajaran (Sudaryono, 2006: 1). Sebagai akibat, tujuan pembelajaran untuk memahamkan hakikat geografi dengan benar kepada siswa tidak pernah tercapai. Keluhan dan kenyataan bahwa pembelajaran geografi tidak menarik dan membosankan masih sering terdengar dan sangat dirasakan. Hal ini disebabkan guru geografi belum mampu membelajarkan geografi kepada siswa dengan pendekatan konstruktivistik menekankan objek formal studi geografi.

Geografi sebagai mata pelajaran formal pertama yang membawa siswa kontak langsung dengan realitas yang dijumpai dalam kehidupan, seharusnya dapat menjadi satu mata pelajaran yang cukup menarik. Bahkan arti penting geografi bagi kehidupan diakui juga oleh tokoh atau pejabat dari kalangan militer maupun pemerintahan dan masyarakat (Suharyono \& Amien, 2013: 323). Geografi dalam kenyataannya kurang menarik bagi banyak siswa tentu ada penyebabnya.

Salah satu penyebab pelajaran geografi tidak menarik ialah terletak pada pendekatan yang digunakan. Hasil pengawasan terhadap perangkat pembelajaran guru-guru geografi di Kabupaten Gresik dari 2011 sampai dengan 2014 ternyata pengembangan desain pembelajaran geografi belum menggunakan pendekatan konstruktivistik yang menekankan objek formal dan masih terpasung pendekatan behavioristik dengan strategi penyampaian materi ilmu bantu geografi, sehingga kurang dapat membangkitkan minat belajar. Akibatnya, geografi oleh sebagian besar siswa dirasakan membosankan.

Suatu pendekatan baru dalam pembelajaran geografi yang memberikan peluang terjadinya proses aktif siswa mengonstruksi sendiri wawasan geografi, memanfaatkan sumber belajar yang beragam, adanya peluang siswa melakukan studi lapangan atau studi archival melalui penggunaan peta secara optimal, dan berpikir geografis yang divergen ialah pembelajaran geografi dengan pendekatan konstruktivistik. Pendekatan konstruktivistik ini sesuai dengan esensi manusia sebagai seorang geograf.

Pendekatan konstruktivistik dalam tujuan pembelajaran geografi menekankan belajar bagaimana belajar, menciptakan pemahaman baru, mengkreativitas dalam konteks nyata, dan 
mendorong siswa untuk berpikir ulang. Siswa juga melakukan studi/kerja lapangan didukung studi archival melalui pemanfaatan peta sehingga mampu berpikir dan bertindak secara geografis. "Siswa mengonstruksi geographical knowledge, skills, dan understanding" (Fisher, tanpa tahun: 24).

Sebuah desain sistem pembelajaran dengan pendekatan konstruktivistik sangat dibutuhkan guru (Gagnon \& Collay, 2001: 7-10). Model desain ini terdiri atas enam komponen: (1) situasi, berupa tujuan pembelajaran dan tugas yang perlu diselesaikan siswa, (2) pengelompokan, dilakukan secara acak (random) atau menurut kriteria tertentu (purposive), siswa diberi kesempatan untuk berinteraksi dengan sejawat, (3) pengaitan, menghubungkan pengetahuan yang telah dimiliki siswa dengan pengetahuan baru melalui pemecahan masalah atau diskusi topik-topik spesifik, (4) pertanyaan, pengajuan pertanyaan merupakan hal penting da-lam pembelajaran karena akan memunculkan gagasan asli sehingga siswa dapat membangun pengetahuan di dalam dirinya, (5) ekshibisi, siswa diberikan kesempatan menunjukkan hasil belajar, dan (6) refleksi, guru dan siswa diberikan ke-sempatan berpikir kritis tentang pengalaman pembelajaran yang telah dilakukan, dan siswa juga diberikan kesempatan berpikir tentang aplikasi pengetahuan yang telah mereka miliki. Kinniburg (2010: 76), menjelaskan bahwa model desain itu termasuk metodologi berbasis teori pembelajaran konstruktivistik.

Model desain pembelajaran konstruktivistik tersebut dikembangkan pada mata pelajaran geografi sebagai temuan baru di bidang desain pembelajaran geografi dengan sintaks: invitasi, eksplorasi, konsolidasi, ekshibisi, evaluasi. Tahap invitasi (situasi), mengaktifkan memori atau pikiran siswa melalui menyampaikan tujuan dan manfaat pembelajaran, dan tugas yang perlu diselesaikan siswa.

Tahap pengelompokan dan eksplorasi, siswa diberi kesempatan berinteraksi dengan sejawat, mengamati langsung (field study) atau tidak langsung (archival study), menanya, dan menggali informasi. Tahap konsolidasi pembelajaran, negosiasi dalam rangka mencapai pengetahuan baru dengan cara menganalisis, mengaitkan pengetahuan yang telah dimiliki dengan pengetahuan baru melalui diskusi topik geografi, dan menyimpulkan dalam bentuk tulisan.

Tahap ekshibisi, siswa diberikan kesempatan menyajikan karya geografi atau membangun jejaring melalui presentasi, dipajang di mading, atau diunggah di internet. Selain itu, siswa juga dituntut melakukan ikrar menerapkan ilmu geografi dalam kehidupan. Tahap refleksi dan evaluasi formatif untuk mendapatkan umpan balik baik untuk guru maupun siswa.

Model desain pembelajaran geografi dengan pendekatan konstruktivistik sebagai temuan baru memiliki sejumlah kelebihan. Beberapa kelebihan tersebut antara lain: (1) melibatkan siswa pada kehidupan, dari lokasi dan ruang konkret, (2) mendorong berpikir divergen yang geografis, (3) fleksibel untuk field study dan archival study, (4) mengembangkan keterampilan pemecahan masalah secara kolaborasi, (5) menerapkan sikap dan perilaku geografis, (6) membangun wawas-an geografi, (7) mendorong siswa menyenangi belajar geografis melalui menga-mati fenomena geosfer dengan perspektif geografi. "Ruang, tempat, lingkungan, dan peta sebagai kunci pembelajaran geografi" (Matthews \& Herbert, 2004: 377).

Penelitian penerapan pendekatan konstruktivistik model pembelajaran geografi berbasis masalah menunjukkan bahwa siswa menjadi aktif kreatif dengan pemahaman geospasial yang lebih besar dan pencapaian kompetensi, bukan reten-si pengetahuan geografi untuk kepentingan diri sendiri (Pawson, dkk., 2006: 103; Beringer, 2007: 445). Hal ini terjadi karena fokusnya adalah siswa mencoba menyelesaikan masalah dan bekerja kolaborasi melalui studi lapangan atau penelitian lapangan dan studi archival dalam rangka belajar sepanjang hayat.

Temuan lainnya menunjukkan bahwa siswa yang mengikuti pembelajaran konstruktivistik model kerja lapangan dalam pembelajaran geografi dan penerapan pembelajaran berbasis masalah melalui investigasi memberi pengaruh positif terhadap partisipasi siswa dalam penelitian lapangan untuk memperoleh informasi geospasial dan keterampilan geografis (Kent; Gilbertson; \& Hunt, 1997: 313 ). Hal ini dapat meningkatkan pemahaman spasial siswa, kemampuan analisis dan interpretasi, dalam mengamati fenomena geografi (Prasad, 2013: 111) sesuai dengan tuntutan geografi sebagai ilmu observasional (Saleh, 1996: 148). 
Berdasarkan permasalahan tersebut ternyata pembelajaran saat ini sebagian besar masih menggunakan desain pembelajaran geografi dengan pendekatan behavioristik. Pendekatan ini menekankan bahwa belajar ialah perolehan dan penambahan pengetahuan siswa. Pola pembelajaran geografi masih berorientasi penyam-paian materi sebagai produk, belum cara mendapatkan ilmu sebagai proses, dan desain pembelajaran geografi belum menggunakan pendekatan konstruktivistik menekankan objek formalnya sehingga geographic eye belum dikuasai siswa.

Tuntutan abad pengetahuan dan globalisasi, pembelajaran harus diarahkan bagaimana membelajarkan dengan menekankan proses aktif siswa membangun sendiri wawasan geografi. Guru memposisikan sebagai salah satu sumber belajar, memberi peluang kepada siswa memanfaatkan sumber belajar secara beragam dan berkolaborasi, belajar secara proaktif dan kreatif dalam perspektif geografi. Pembelajaran geografi yang memenuhi karakteristik dimaksud di atas dike-nal dengan pendekatan konstruktivistik. Untuk maksud tersebut, perlu dilakukan pengembangan desain pembelajaran geografi dengan menggunakan pendekatan konstruktivistik yang berawal dari merancang produk, uji coba produk, dan merevisi produk yakni berupa model DPK dan perangkat pembelajaran geografi.

Sejalan dengan permasalahan di atas maka tujuan penelitian pengembangan ini adalah menghasilkan desain pembelajaran geografi dengan pendekatan konstruktivistik. Produk desain tersebut meliputi: (1) model desain pembelajaran geografi dengan pendekatan konstruktivistik (model DPK), (2) rencana pelaksanaan pembelajaran (RPP), (3) bahan ajar geografi (BAG), (4) lembar kegiatan siswa (LKS), dan (5) lembar evaluasi belajar (LEB).

\section{Metode}

Metode penelitian pengembangan ini mencakup dua landasan, yaitu: konseptual pengembangan dan model pengembangan. Landasan konseptual pengembangan merupakan dasar konseptual pembelajaran yang dipilih, digunakan sebagai landasan pengembangan desain merujuk pada tiga hal, yakni paradigma, model desain, prosedur pembelajaran, yaitu CLD dari Gagnon \& Collay (2001). Landasan model pengembangan menggunakan C-ID dari Willis \& Wright (2000) melalui pola kerja R2D2.

Paradigma pembelajaran yang dijadikan pijakan dalam pengembangan ini ialah dengan pendekatan konstruktivistik. Paradigma ini memandang bahwa siswa secara individu dan/atau kolaborasi membangun sendiri wawasan dan keterampilan kegeografiannya. Siswa mampu menerapkan pendekatan spasial dalam kehidupan sehari-hari ketika melakukan kajian fenomena geosfer.

Desain pembelajaran dengan pendekatan konstruktivistik menekankan siswa aktif mengonstruksi wawasan dan keterampilan kegeografiannya sendiri. Mereka berinteraksi dengan beragam sumber belajar, kemudian menentukan apa yang akan mereka pelajari. Kunci teori konstruktivistik menekankan bahwa orang belajar secara aktif membangun pengetahuan mereka sendiri, membandingkan informasi baru dengan pemahaman sebelumnya dan menggunakannya untuk menghasilkan pemahaman baru. Siswa tidak sekadar menerima atau menyerap informasi geografis yang ia terima dari guru geografi atau dari buku teks geografi, tetapi siswa sendiri membangun suatu pengetahuan baru.

Model sebagai abstraksi sesuatu yang dipakai untuk membantu memahami suatu objek atau peristiwa yang tidak dapat dilihat atau dialami secara langsung (Mustaji, 2010a: 190, 2010b: 18). Model umumnya tidak menggambarkan secara detail kenyataan, tetapi hanya bagian tertentu yang penting atau merupakan sosok kunci atau hal-hal yang relevan saja. Joyce, Weil, \& Calhoun (2011: 7) mengemukakan, "model pembelajaran dapat digunakan untuk menyusun kurikulum, merancang bahan pelajaran, dan menuntun pelajaran di kelas atau pada kondisi lainnya". Dalam pengertian inilah disebut model pembelajaran yang akan dikembangkan.

Landasan prosedur pembelajaran yang dijadikan pijakan dalam pengem-bangan ini ialah prosedur pembelajaran konstruktivistik dengan metode field study dan/atau archival study, serta proses saintifik. Desain pembelajaran konstruktivistik ini dilandasi prosedur desain pembelajaran konstruktisvistik atau CLD (model Gagnon \& Collay, 2001; model konstruktivistik 
Diknas (Zamroni, 2000). CLD yang diajukan Gagnon \& Collay (2001) meliputi: situasi, pengelompokan, pengaitan, pertanyaan, penyajian, dan refleksi.

Prosedur pembelajaran geografi tersebut dilandasi filsafat konstruktivisme dan proses saintifik, kemudian dikembangkan menjadi suatu model desain instruksional yakni model desain pembelajaran konstruktivistik (DPK) yang saintifik dengan lima prosedur pembelajaran ialah (1) invitasi (menyampaikan tujuan dan tugas), (2) pengelompokan dan eksplorasi (mengamati, menanya, mengumpulkan data melalui tim belajar), (3) konsolidasi pembelajaran (menganalisis, mengaitkan dan menyimpulkan data), (4) ekshibisi (mengomunikasikan hasil belajarnya dan ikrar mengamalkan geografi), (5) refleksi dan evaluasi.

Landasan model pengembangan yang digunakan sebagai pijakan dalam desain pembelajaran dengan pendekatan konstruktivistik ialah model Constructivist Instructional Design (C-ID) dari Willis \& Wright (2000). C-ID ialah suatu model pengembangan dengan menggunakan pendekatan konstruktivistik melalui pola kerja R2D2 (Reflective, Recursive, Design, and Development). Model R2D2 ini memiliki tujuh karakteristik, yaitu (1) proses pengembangan pembelajaran bersifat rekursif, nonlinier, dan kadang-kadang semrawut; (2) desain bersifat organik, ber-sifat pengembangan, reflektif, dan kolaboratif; (3) tujuan muncul dari pekerjaan merancang dan pengembangan; (4) pakar pengembangan pembelajaran yang ber-sifat umum tidak ada; (5) pembelajaran menekankan belajar dalam konteks yang bermakna; (6) evaluasi formatif menentukan; dan (7) data subjektif lebih bernilai (Willis \& Wright, 2000).

Pengembangan model pembelajaran yang berpijak pada pandangan konstruktivisme berbeda dengan pandangan behaviorisme. Model pengembangan pembelajaran konstruktivistik memiliki beberapa karakteristik, antara lain: (1) proses pengembangan pembelajaran bersifat rekursif, tidak linier, dan tidak ada kepastian (chaos), (2) desain bersifat refleksi dan kolaborasi, (3) tujuan muncul dari pekerjaan desain dan pengembangan, (4) pembelajaran menekankan pada belajar dalam konteks yang bermakna, (5) evaluasi formatif menentukan, dan (6) data subjektif lebih bernilai.

Pengembangan model pembelajaran yang berpijak pada struktur model C-ID itu terdiri atas empat tahap, yakni (1) pendefinisian atau penetapan (define); (2) perancangan atau desain (design), (3) pengembangan (development), dan (4) diseminasi (dissemination). Fokus pendefinisian dilakukan dengan cara membentuk tim pengembang (team partisipatory). Tugas tim ada tiga, yakni (1) menciptakan dan mendukung tim partisipasi, (2) melakukan pemecahan masalah secara progresif, dan (3) mengembangkan pronesis atau pemahaman kontekstual.

Desain dan pengembangan merupakan satu kesatuan yang tidak dapat dipisahkan, karena terkait dengan pengembangan pronesis dan solusi atau pemecahan masalah secara progresif. Ada empat aktivitas yang perlu dilakukan dalam desain dan pengembangan ini, yakni: (1) memilih lingkungan pengembangan, (2) memilih format produk dan media, (3) menentukan format evaluasi, dan (4) mendesain dan mengembangkan produk.

Prosedur pengembangan desain pembelajaran geografi dengan pendekatan konstruktivistik ini meliputi lima tahap. Pertama, Tahap Identifikasi. Ada tiga kegiatan yang dilakukan oleh pengembang pembelajaran pada tahap ini, yakni (1) melakukan kajian teoretis melalui studi pustaka, (2) melakukan kajian empiris melalui observasi di kelas. Kajian teoretik diperlukan dalam mengawali kegiatan pengembangan agar mendapatkan sejumlah informasi dan produk model desain pembelajaran dan perangkat pembelajaran yang direncanakan. Kajian dimaksud berupa kajian pustaka, hasil penelitian atau penelitian sebelumnya yang relevan, jurnal riset pendidikan geografi, dan berbagai informasi yang terkait dengan desain instruksional dan implementasi model pembelajaran yang akan dikembangkan.

Kedua, Tahap Desain. Ada tiga kegiatan yang dilakukan peneliti pada tahap desain, yaitu (1) mengidentifikasi kemampuan awal siswa, (2) merumuskan tujuan pembelajaran, dan (3) melakukan studi kelayakan. Kegiatan desain dilakukan oleh sebuah tim. Tugas tim ada tiga, yaitu (1) menciptakan dan mendukung tim pengembang partisipasi; (2) memecahkan masalah secara progresif; dan (3) mengembangkan pronesis atau pemahaman kontekstual.

Ketiga, Tahap Pengembangan. Tahap pengembangan ini dilakukan pengembangan kategori produk, yakni: (1) model desain pembelajaran geografi dengan pendekatan 
konstruktivistik, disingkat model DPK, dan (2) perangkat pembelajaran. Produk tersebut dimplementasikan pada Kurikulum 2013 khususnya mata pelajaran peminatan geografi.

Keempat, Tahap Uji Coba. Kegiatan uji coba ini terdiri atas tiga tahap, yakni (1) uji ahli, (2) uji kelompok, dan (3) uji lapangan. Uji ahli dilakukan dua orang ahli pendidikan geografi yang berkompetensi di bidang (1) desain pembelajaran, dan (2) isi bidang studi. Ahli isi bidang studi, diharapkan dapat memberikan masukan tentang kebenaran isi, kekinian, dan organisasi isi bidang studi geografi yang dilabeli empat komponen inti, yaitu ruang, tempat, lingkungan, dan peta. Sebaliknya, Ahli desain pembelajaran geografi, diharapkan dapat memberikan masukan tentang kelayakan, efektivitas, dan kemenarikan model desain pembelajaran yang dikembangkan dengan harapan siswa mampu membangun penge-tahuan secara mandiri.

Kelima, Tahap Diseminasi. Paket produk desain akhir ini disebarkan kepada pihak yang terkait terutama guru geografi terbatas pada guru geografi SMA di lingkungan Dinas Pendidikan Kabupaten Gresik. Produk desain ini dapat diadopsi dalam konteks pembelajaran pada mata pelajaran sejenis atau bidang studi yang relevan. Kegiatan lain ialah menyajikan hasil pengembangan dalam suatu jurnal pembelajaran.

\section{Hasil dan pembahasan}

\subsection{Reviu Ahli Desain Pembelajaran Geografi}

Reviu produk pengembangan desain pembelajaran geografi dengan pendekatan konstruktivistik yang menekankan saintifik dilakukan oleh dua orang ahli pendidikan geografi dan berkemampuan di bidang desain pembelajaran geografi (disebut ahli desain pembelajaran geografi). Ada lima jenis produk pengembangan yang akan ditelaah, yaitu (1) model DPK, (2) rencana pelaksanaan pembelajaran, (3) bahan ajar geografi, (4) lembar kegiatan siswa, dan (5) lembar evaluasi belajar. Setelah ditelaah oleh ahli pendidikan geografi bidang desain pembelajaran dan memperoleh masukan dari pembimbing serta praktisi pendidikan geografi melalui seminar maka perangkat pembelajaran berupa RPP, BAG, LKS, dan LEB diujicobakan di SMA Negeri 1 Sidayu dan SMA Negeri 1 Kebomas.

Hasil reviu model DPK oleh pereviu 1 dinilai 80, kategori cukup layak, perlu direvisi, sedangkan oleh pereviu 2 dinilai 88, kategori layak, tidak perlu direvisi. Revisi model DPK di antaranya (1) ditambah uraian filsafat konstruktivisme dan filsafat pembelajaran konstruktivistik, (2) sintaks model DPK diadopsi dari model CLD Gagnon \& Collay, dan (5) diberikan contoh penerapan objek formal geografi dalam pembelajaran konstruktivistik.

Hasil reviu model RPP oleh pereviu 1 dinilai 87, kategori layak, tidak perlu direvisi, sedangkan oleh pereviu 2 dinilai 79, kategori cukup layak, perlu direvisi. Revisi RPP antara lain: (1) dilengkapi lembar observasi aspek spiritual dan sosial, (2) pada tahap ekshibisi dapat melalui presentasi, dipajang di mading, atau diunggah di internet, (3) skenario di RPP dibuat secara realistik, dan (4) tes uraian disertai kisi-kisi soal dan penskoran.

Hasil reviu BAG oleh pereviu 1 dinilai 80, kategori cukup layak, perlu direvisi, sedangkan oleh pereviu 2 dinilai 91, kategori sangat layak, tidak perlu direvisi. Revisi bahan ajar geografi meliputi (1) pertanyaan direvisi mengarah siswa mengutarakan ide, menyimpulkan dan mengonstruksi pengetahuan secara mandiri, (2) aspek fisik dan manusia, dilengkapi skema yang menunjukkan interaksi manusia dengan lingkungan, (3) dicantumkan peta konsep pada awal setiap topik, (4) dilengkapi ringkasan dan glosarium, (5) bagian topik pendekatan geografi dilengkapi dengan sembilan tema untuk pendekatan spasial, dan empat tema untuk pendekatan ekologikal, dan (6) tampilan fisik bahan ajar ditata sedemikian rupa sehingga indah dan menarik.

Hasil reviu LKS oleh pereviu 1 dinilai 82, kategori layak, tidak perlu direvisi, sedangkan oleh pereviu 2 dinilai 92, kategori sangat layak, tidak perlu direvisi. Revisi LKS ini antara lain (1) beberapa soal diubah ke arah siswa diberikan kesempatan untuk "mengkritisi" konsep atau fakta yang disajikan dalam materi, (2) petunjuk diperjelas terhadap tugas/analisis yang dilakukan siswa, (3) diberi alokasi waktu pada setiap pelaksanaan pengerjaan lembar kegiatan tersebut, dan (4) disediakan lembar kosong untuk menuangkan hasil analisis dan simpulan.

Hasil reviu LEB oleh pereviu 1 dinilai 80, kategori cukup layak, perlu direvisi, sedangkan oleh pereviu 2 dinilai 100, kategori sangat layak, tidak perlu direvisi. Revisi LEB meliputi (1) 
pertanyaan memberi kesempatan siswa untuk berkreasi yang mengarah pada konstruksi pikiran masing-masing siswa, (2) dilengkapi kisi-kisi soal, (3) kunci jawaban dan pedoman penskoran, dan (4) pertanyaan diubah dengan kalimat yang mudah dipahami siswa.

\subsection{Uji Kelompok Guru dan Siswa}

Uji coba produk desain pembelajaran konstruktivistik berupa (1) model DPK, (2) RPP, (3) BAG, (4) LKS, dan (5) LEB kepada 15 guru geografi yang tergabung dalam MGMP Geografi SMA Kabupaten Gresik. Uji kelompok ini dilaksanakan hari Sabtu, 12 Juli 2014 dalam bentuk seminar dan bedah lima produk desain instruksional konstruktivistik, dan diakhiri dengan mengisi angket.

Uji kelompok tersebut bertujuan memperoleh masukan sebagai bahan merevisi kualitas lima produk desain dengan harapan model desain pembelajaran konstruktivistik dan perangkatnya lebih layak, lebih efektif, dan lebih menarik sehingga proses pembelajaran menjadi menyenangkan. Hal ini didukung oleh pendapat Hernowo (2007: 17), menyenangkan dimaknai bangkitnya minat, adanya keterlibatan penuh, terciptanya makna, penguasaan materi, dan nilai yang membahagiakan bagi siswa. Desain instruksional dibuat untuk mempermudah siswa belajar. Hasil uji coba produk kepada kelompok guru geografi dapat dilihat pada Tabel 1.

Tabel 1 Hasil Uji Coba Produk Model DPK dan Perangkat Pembelajaran Geografi kepada Kelompok Guru

\begin{tabular}{|c|c|c|c|}
\hline No. & Kriteria & Hasil (\%) & Saran \\
\hline 1. & $\begin{array}{l}\text { Prosedur model DPK } \\
\text { disusun realistik dan } \\
\text { proses saintifik }\end{array}$ & $\begin{array}{l}80 \text { (realistik dan saintifik), } \\
20 \text { (kurang realistik dan } \\
\text { saintifik) }\end{array}$ & $\begin{array}{l}\text { (1) model DPK perlu } \\
\text { ditambah peran guru dan } \\
\text { siswa dalam pembelajaran }\end{array}$ \\
\hline 2. & $\begin{array}{l}\text { Kesesuaian RPP dengan } \\
\text { model DPK }\end{array}$ & 100 (sesuai) & $\begin{array}{l}\text { konstruktivistik, kata } \\
\text { pengantar, daftar isi, dan }\end{array}$ \\
\hline 3. & $\begin{array}{l}\text { Kemenarikan dan } \\
\text { kecukupan tampilan dan isi }\end{array}$ & $\begin{array}{l}\text { 66,67 (kemenarikan dan } \\
\text { kecukupan), 33, } 33 \\
\text { (kekurangmenarikan dan } \\
\text { kecukupan) }\end{array}$ & $\begin{array}{l}\text { penutup; (2) BAG, gambar } \\
\text { dan peta perlu diperjelas, } \\
\text { tampilan perlu didesain } \\
\text { menarik, pendekatan }\end{array}$ \\
\hline 4. & $\begin{array}{l}\text { Kualitas LKS mampu } \\
\text { membangun wawasan } \\
\text { kegeografian }\end{array}$ & $\begin{array}{l}66,67 \text { (tinggi), } 33,33 \\
\text { (sedang) }\end{array}$ & $\begin{array}{l}\text { geografi perlu diuraikan, dan } \\
\text { (3) LEB, pertanyaan perlu } \\
\text { menggunakan bahasa }\end{array}$ \\
\hline 5. & $\begin{array}{l}\text { Kuantitas dan kualitas } \\
\text { latihan mencukupi sesuai } \\
\text { dengan tuntutan } \\
\text { pendekatan } \\
\text { konstruktivistik }\end{array}$ & $\begin{array}{l}73,33 \text { (mencukupi), 26,67 } \\
\text { (kurang mencukupi) }\end{array}$ & komunikatif. \\
\hline
\end{tabular}

Uji coba pembelajaran dilaksanakan terhadap siswa kelas X MIPA-3 Lintas Minat Geografi SMA Negeri 1 Sidayu dan kelas X IPS-1 SMA Negeri 1 Kebomas dengan jumlah siswa seluruhnya 64 orang. Selama uji coba pembelajaran di kedua SMA tersebut, semua siswa yang dijadikan subjek uji coba tidak ada yang absen. Subjek uji coba ditetapkan sebanyak 64 orang. Selama uji coba pembelajaran semua indikator proses dan hasil belajar itu dicatat, dan didokumentasikan untuk mengetahui perkembangan nilai siswa.

Uji coba bahan ajar geografi dimaksudkan untuk memperoleh tanggapan siswa terhadap bahan ajar geografi yang dikembangkan. Tanggapan dimaksud

mencakup kedalaman dan keluasan, kemudahan untuk dapat dipahami, dan penggunaan bahan pembelajaran sebagai salah satu sumber belajar yang esensial dan memotivasi siswa dalam menemukan ide geografis. Pilihan jawaban siswa dalam angket digunakan untuk merevisi dan melengkapi bahan ajar geografi. Hasil uji coba bahan ajar geografi kepada kelompok siswa yang memilih peminatan IPS dan lintas minat mata pelajaran geografi dapat dilihat pada Tabel 2. 
Tabel 2 Hasil Uji Coba Bahan Ajar Geografi kepada Kelompok Siswa

\begin{tabular}{cll}
\hline No. & \multicolumn{1}{c}{ Kriteria } & \multicolumn{1}{c}{ Hasil (\%) } \\
\hline 1. & Keluasan BAG yang dikembangkan & 25 (lebih luas),75 (luas) \\
2. & $\begin{array}{l}\text { Kesesuaian antara materi, tugas yang } \\
\text { diberikan, dan lingkungan belajar }\end{array}$ & 93,75 (sesuai), 6,25 (kurang sesuai) \\
3. & $\begin{array}{l}\text { Kemudahan memahami topik dan } \\
\text { bahasa yang digunakan }\end{array}$ & 87,6 (mudah dipahami),12,5 (sulit dipahami) \\
4. & $\begin{array}{l}\text { Contoh yang disajikan } \\
\text { 5. }\end{array}$ & Ketepatan indikator pencapaian hasil \\
& belajar dengan materi yang dibahas & 100 (semua tepat) \\
6. & Besar huruf dan spasi yg digunakan & 100 (cukup) \\
7. & Kejelasan gambar dan peta & 81,25 (cukup jelas), 18,75 (kurang jelas) \\
8. & Kebaruan konsep, teori, dan data & 87,5 (baru), 12,5 (lama) \\
9. & Komponen yang perlu ditambahkan & 18,75 (ringkasan dan glosarium); 15,63 \\
& & (glosarium dan referensi); 65,62 (ringkasan, \\
& & glosarium, referensi) \\
\hline
\end{tabular}

\subsection{Uji Coba Lapangan}

Uji coba pembelajaran konstruktivistik berdasarkan hasil observasi aktivitas guru dan siswa di SMAN 1 Sidayu masing-masing mencapai 86,67\%, sedangkan aktivitas guru dan siswa di SMAN 1 Kebomas mencapai $100 \%$ dan 86,67\%. Agar proses dan hasil mencapai optimal, siswa harus menguasai prinsip belajar konstruktivistik dan peran guru sebagai motivator, fasilitator, dan konsultan. Perkembangan nilai tim dari 16 tim belajar sebanyak 14 tim belajar memperoleh rerata perkembangan nilai $\geq 25$ dengan predikat super dan 2 tim belajar mendapatkan nilai berkisar 20-24 dengan predikat hebat. Respon mayoritas siswa terhadap pembelajaran konstruktivistik ialah menyenangkan. Hasil uji coba perangkat pembelajaran yang dikembangkan dari model DPK meliputi aktivitas guru dan siswa, serta respon siswa terhadap penerapan pembelajaran tersebut bisa dilihat pada Tabel 3 .

Tabel 3 Uji Coba Model Desain Pembelajaran dengan Pendekatan Konstruktivistik

\begin{tabular}{|c|c|c|c|c|}
\hline No. & Aspek yang dinilai & Kriteria & Hasil (\%) & Keterangan \\
\hline \multirow[t]{5}{*}{1.} & Aktivitas Guru & & & \\
\hline & SMAN 1 Sidayu & ya & 86,67 & - \\
\hline & & tidak & 13,33 & $\begin{array}{l}\text { Perlu perbaikan yakni prinsip } \\
\text { pembelajaran konstruktivistik } \\
\text { perlu dikuasai guru geografi. }\end{array}$ \\
\hline & SMAN 1 Kebomas & ya & 100 & Guru menguasai model DPK \\
\hline & & tidak & 0 & - \\
\hline \multirow[t]{5}{*}{2.} & \multicolumn{4}{|c|}{ Aktivitas Siswa } \\
\hline & \multirow[t]{2}{*}{ SMAN 1 Sidayu } & ya & 86,67 & - \\
\hline & & tidak & 13,33 & $\begin{array}{l}\text { Diskusi secara demokratis, } \\
\text { pertukaran ide secara terbuka, } \\
\text { divergen, reflektif, dan } \\
\text { interpretasi. }\end{array}$ \\
\hline & \multirow[t]{2}{*}{ SMAN 1 Kebomas } & ya & 86,67 & - \\
\hline & & tidak & 13,33 & $\begin{array}{l}\text { Berpikir divergen, reflektif, } \\
\text { interpretasi, mengembangkan } \\
\text { perilaku proaktif dalam } \\
\text { mempelajari peran geografi } \\
\text { dalam kehidupan. }\end{array}$ \\
\hline \multirow[t]{4}{*}{3.} & Respon siswa terhadap & & & \multirow{4}{*}{$\begin{array}{l}\text { Materi pelajaran geografi } \\
\text { menarik untuk dipelajari dan } \\
\text { diterapkan. }\end{array}$} \\
\hline & a. materi pelajaran & menarik & 85,94 & \\
\hline & & tidak menarik & 7,81 & \\
\hline & & tidak beride & 6,25 & \\
\hline
\end{tabular}




$\begin{array}{clrl}\text { b. lembar kegiatan } & \text { menarik } & 84,38 & - \\ & \text { tidak menarik } & 6,25 & \\ & \text { tidak beride } & 9,37 & \\ \text { c. model DPK } & \text { menarik } & 87,5 & \text { Belum terbiasa dgn model } \\ & \text { tidak menarik } & 12,5 & \begin{array}{l}\text { DPK, guru tidak menjelaskan } \\ \text { materi secara rinci dan utuh. }\end{array} \\ \text { d. interaksi antara } & \text { menyenangkan } & 89,06 & - \\ \text { guru dan siswa } & \text { tidak beride } & 10,94 & \\ & \text { menyenangkan } & 100 & - \\ \text { e. interaksi antara } & & \\ \text { siswa dan siswa } & & \end{array}$

\subsection{Pembahasan}

Model DPK dikembangkan dari CLD Gagnon dan Collay (2001: 7) sebagai temuan baru yang berbeda dengan model-model desain instruksional yang pernah ada. Model DPK bersintaks: invitasi, pengelompokan dan eksplorasi, konsolidasi pembelajaran, ekshibisi, dan refleksi/evaluasi dengan harapan dapat memperbaiki/ meningkatkan mutu pembelajaran geografi dengan indikasi pembelajaran geografi lebih menonjolkan objek formal geografi, efektif, efisien, menarik atau menyenangkan sehingga siswa proaktif dan responsif dalam mengkaji isu geografis.

Menyenangkan dalam model DPK mengarah pada bangkitnya minat, ada keterlibatan penuh, terciptanya makna, penguasaan materi, dan nilai yang membahagiakan. Model DPK yang menyenangkan dapat mengantarkan siswa menjadi seorang geograf.

RPP dilengkapi: (1) KI-1 dan KI-2, dibuatkan lembar observasi tersendiri untuk mendeteksi aspek perilaku siswa dalam belajar yang mengarah pada aspek ketuhanan dan kemanusiaan, (2) pada tahap ekshibisi, siswa membangun jejaring dalam bentuk menyajikan karya belajar melalui presentasi, dipajang di mading atau diunggah di internet, (3) skenario di RPP disajikan secara realistik terhadap apa yang akan dilaksanakan, (4) pada bagian evaluasi ditambahkan indikator pada lembar observasi sikap beserta rubriknya, (5) evaluasi hasil belajar dengan bentuk tes uraian disertai kisi-kisi soal, kunci jawaban, dan penskoran untuk menghindari subjektivitas. RPP Geografi didesain dengan sistematis, lengkap, realistis, dan praksis.

RPP didesain dengan menonjolkan objek formal geografi ketika proses pembelajaran berlangsung dan lembar observasi harus disiapkan terutama yang berkenaan dengan KI-1 dan KI-2. Pembelajaran geografi di sekolah menengah atas perlu penekanan objek formal geografi dengan cara memandang dan cara berpikir terhadap fenomena di muka bumi dari aspek keruangan yang meliputi pola, sistem, dan proses agar geographical eye dikuasai siswa.

Bahan ajar geografi dilengkapi: (1) pilihan masalah yang memberikan kesempatan kepada siswa mengutarakan ide, menyimpulkan dan mengonstruksi pengetahuan secara mandiri, (2) skema mengenai aspek fisik dan manusia yang menunjukkan adanya komponen fisik geografi dan manusia yang saling berkaitan, (3) dicantumkan peta konsep pada awal setiap topik sebagai scaffolding, (4) ringkasan dan glosarium, (5) bagian topik pendekatan geografi dijelaskan sembilan tema untuk pendekatan spasial, dan empat tema untuk pendekatan ekologikal, dan (6) tampilan fisik bahan ajar ditata sedemikian rupa sehingga indah dan menarik. Bahan ajar geografi tersebut didesain dengan maksud sebagai salah satu sumber belajar yang dilengkapi label geografi yakni ruang, tempat, lingkungan, dan peta sehingga siswa merasakan manfaat belajar geografi yang sebenarnya bukan ilmu-ilmu bantu geografi.

Bahan ajar geografi didesain dengan sistematika berbeda dengan produk pengembangan yang pernah ada sebelumnya yang menempatkan bahan ajar pada urutan pertama. Dalam pembelajaran konstruktivistik pengembang tidak menspesifikasi bahan ajar geografi yang harus dipelajari siswa, karena siswa diharapkan membangun wawasan geografinya sendiri 
berdasarkan pengalaman dan pengetahuan yang telah dimiliki sebelumnya sehingga menjadi konstruksi dalam pikiran setiap siswa dengan sudut pandang geografi.

LKS dilengkapi: (1) siswa diberikan kesempatan untuk mengkritisi konsep atau fakta yang disajikan dalam materi, (2) petunjuk yang jelas terhadap tugas/ analisis yang dilakukan siswa, (3) alokasi waktu pada setiap pelaksanaan pengerjaan lembar kegiatan tersebut, dan (4) disediakan lembar kosong untuk menuangkan hasil analisis dan simpulan atau ide-ide dalam membangun wawasan geografi. LKS didesain sebagai strategis pembelajaran yang menekan metodologi pembelajaran bukan berisi latihan soal-soal melainkan sebagai sarana belajar dan bekerja layaknya seorang geograf. Pilihan masalah berupa pertanyaan geografis menekan-kan analisis (mengapa), sintesis (bagaimana), dan studi atau kerja lapangan.

Lembar evaluasi belajar ini dilengkapi: (1) pilihan soal memberikan kesempatan kepada siswa untuk berinovasi/berkreasi yang mengarah pada konstruksi pikiran masing-masing siswa, (2) kisi-kisi soal, (3) kunci jawaban dengan pedoman penskoran, dan (4) beberapa pertanyaan diubah dengan kalimat yang mudah dipahami siswa. Pilihan soal memberikan kesempatan kepada siswa untuk mengutarakan idenya, memberi komentar, dan menjawab pertanyaan dengan mencari solusi terhadap isu-isu geosfer dengan menggunakan sudut pandang geografi.

Keunggulan produk pengembangan desain pembelajaran geografi dengan pendekatan konstruktivistik sebagai temuan baru berupa model DPK dan perangkat pembelajarannya dapat diuraikan secara rinci sebagai berikut.

Pertama, mempertimbangkan bahwa belajar ialah proses mengonstruksi pengetahuan dari pengalaman konkrit, aktivitas kolaborasi, refleksi, dan interpretasi. Pembelajaran ialah menata lingkungan supaya siswa termotivasi dalam menggali makna dan menghargai ketidakpastian. Indikasi produk perangkat pembelajaran yang dikembangkan menekankan guru sebagai motivator, fasilitator, pembimbing, dan konsultan profesional untuk menghantarkan siswa sebagai pembangun ilmu sekaligus sebagai peneliti, dan penemu konsep kegeografian.

Kedua, mempertimbangkan bahwa belajar pada hakikatnya memiliki aspek sosial dan siswa yang berbakat tetap mampu belajar bersama siswa lain. Indikasi produk perangkat pembelajaran yang dikembangkan, antara lain: (a) siswa diberikan kesempatan belajar dan melakukan kerja tim, (b) kerja tim konstruktivis dirancang secara acak atau heterogen, (c) siswa diberikan kesempatan berperan secara bervariasi atau beragam, dan (d) dalam evaluasi belajar, guru memperhitungkan proses dan hasil.

Ketiga, mempertimbangkan bahwa siswa membutuhkan suasana bebas dalam mengontrol diri. Indikasi produk perangkat pembelajaran yang dikembangkan ialah siswa diberikan kebebasan dalam mengontrol diri dengan: (a) menerapkan cara belajar yang paling sesuai dengan dirinya, (b) mengevaluasi diri mengenai cara berpikir dan cara belajarnya, (c) tugas nyata yang relevan dengan kehidupan sehari-hari dan kaitannya antara tugas dan pengalaman pribadinya, (d) membahas kaitan antara usaha dan hasil.

Keempat, mempertimbangkan perbedaan atau berbagai gaya belajar kognitif siswa. Indikasi produk perangkat pembelajaran yang dikembangkan adalah tugas-tugas dengan spesifikasi: (a) diberikan peluang kepada siswa untuk menentukan pilihan masalah dan menyelesaikan masalah atau tugas tersebut baik secara mandiri maupun tim konstruktivis, (b) diberikan peluang pilihan bagaiman acara memperlihatkan bahwa siswa telah menguasai bahan pembelajaran yang dikaji, (c) diberikan peluang waktu yang cukup untuk memikirkan dan menyelesaikan tugas, (d) siswa diberikan kesempatan berpikir ulang dan merevisi, dan (e) mengakomodasikan pengalaman konkret siswa dalam menyelesaikan tugas.

Kelima, mempertimbangkan bahwa siswa berbakat cenderung berkuriositas tinggi, berpikir kritis, dan belajar aktif. Indikasi produk perangkat pembelajaran yang dikembangkan, antara lain: (a) siswa didorong berpikir divergen, reflektif, daninterpretatif, (b) disediakan kegiatan yang dapat menjadi luapan pikiran, brainstorming, dan menjelaskan kepada teman, (c) diberikan peluang kepada siswa untuk memiliki keterampilan berpikir kritis, dan (d) memberikan kesempatan kepada siswa melakukan evaluasi diri dan studi lapangan atau fieldwork.

Beberapa kelemahan produk perangkat pembelajaran geografi dengan pendekatan konstruktivistik yang dikembangkan terletak pada tahap implementasinya. Pertama, siswa 
belum menguasai prinsip-prinsip belajar konstruktivistik, terutama belum terbiasa belajar dan bekerja secara kolaborasi sehingga aktivitas mereka belum maksimal dalam usaha membangun pengetahuan dan keterampilan barunya. Kedua, sebagian siswa kurang memiliki kinerja yang membanggakan dalam usaha menguasai kompetensi secara maksimal, baik kecerdasan spiritual, kecerdasan sosial, maupun kecerdasan akademik belum terbentuk secara utuh. Sebaik apapun desain pembelajaran yang dikembangkan tanpa adanya ke-mauan siswa dalam belajar dengan menggunakan prinsip-prinsip konstruktivistik maka hasilnya tentu tidak maksimal. Ketiga, siswa merasa kekurangan waktu dalam usaha mencari, menemukan, memecahkan masalah, memanfaatkan sumber belajar yang beragam, menyajikan, atau unjuk kerja, dan melakukan studi lapangan di lingkungan geografis terdekat, misalnya daerah sekitar sekolah.

Solusi untuk mengatasi beberapa kelemahan di atas, dengan cara guru melakukan hal-hal sebagaimana dijelaskan sebagai berikut. Petama, melakukan pembimbingan kepada siswa dalam memahami dan menerapkan prinsip belajar konstruktivistik agar mereka terbiasa membangun pengetahuan dan keterampilan sendiri, berpikir divergen, reflektif, dan interpretatif terhadap masalah atau fenomena yang dikaji. Kedua, memosisikan dirinya sebagai motivator, fasilitator, dan konsultan atau konselor dalam pelaksanaan pembelajaran dengan mengembangkan pendekatan humanis, mengondisikan suasana lingkungan belajar yang bebas, menyenangkan, dan bermakna bagi siswa sehingga kecerdasan spiritual, sosial, dan akademik dapat terbentuk secara utuh. Ketiga menyediakan waktu secukupnya bagi siswa untuk mencari, menemukan, memecahkan masalah, memanfaatkan sumber belajar yang beragam, menyajikan karya belajar, melakukan studi atau kerja lapangan. Kerja lapangan merupakan komponen kunci dalam pembelajaran geografi seharusnya menjadi tema pokok dalam perencanaan kurikulum.

\section{Simpulan dan saran}

Produk pengembangan desain pembelajaran geografi dengan menggunakan pendekatan konstruktivistik telah direvisi. Produk tersebut meliputi: (1) model desain pembelajaran geografi dengan pendekatan konstruktivistik (model DPK), (2) rencana pelaksanaan pembelajaran (RPP), (3) bahan ajar geografi (BAG), (4) lembar kegiatan siswa (LKS), dan (5) lembar evaluasi belajar (LEB).

Salah satu model desain pembelajaran dengan pendekatan konstruktivistik yang dikembangkan ialah CLD Gagnon dan Collay ke dalam model DPK dengan sintaks: invitasi, pengelompokan dan eksplorasi, konsolidasi pembelajaran, ekshibisi, dan refleksi/evaluasi dengan harapan dapat memperbaiki dan meningkatkan mutu pembelajaran dengan indikasi pembelajaran lebih efektif, efisien, dan menarik, atau menyenangkan.

Pengembangan produk desain pembelajaran ini menggunakan pendekatan konstruktivistik dan diarahkan pada model DPK yang diadopsi dan dikembangkan dari CLD Gagnon \& Collay dengan perangkat pembelajaran pada mata pelajaran geografi. Melalui model desain ini, diharapkan siswa mampu membangun pengetahuan atau keterampilan barunya, mampu berpikir divergen, reflektif, dan interpretatif terhadap masalah atau fenomena geosfer yang dikaji dalam suasana ling-kungan belajar yang bebas, menyenangkan, dan belajar menjadi lebih bermakna.

Model DPK beserta perangkat pembelajarannya disarankan agar dikembangkan dengan model-model pembelajaran berbasis riset, model pembelajaran berbasis masalah, dan model pembelajaran berbasis proyek untuk keperluan pe-ngembangan lebih lanjut pada mata pelajaran geografi atau mata pelajaran sejenis.

Prinsip belajar yang perlu diperhatikan dalam model DPK adalah prinsip konstruktivistik dengan harapan supaya siswa mampu mengembangkan pengetahuan, keterampilan, sikap, dan nilai-nilai geografi dalam menghargai keragaman dalam segala aspek kehidupan baik pada skala daerah, nasional, maupun global.

\section{Daftar Rujukan}

Ardhana, W. 2001. Reformasi Pembelajaran Menghadapi Abad Pengetahuan. Makalah disampaikan dalam kuliah perdana program S2 Teknologi Pembelajaran, Universitas PGRI Adi Buana Surabaya di Gresik, 19 Mei. 
Beringer, J. 2007. Application of Problem Based Learning through Research Investigation. Journal of Geography in Higherv Education, 31(3): 445-457.

Ertmer, P.A. \& Newby, T.J. 2013. Behabiorrism, Cognitivism, Constructivism Comparing Critical Features From an Instructional Design Perspective. Performance Improvement Quarterly, 26(2): 43-71.

Fisher, T. The into Practice: WebQuests in Geography. Geographical Association, Professional Development for Geography Teachers.

Gagnon Jr, G.W. \& Collay, M. 2001. Designing for Learning: Six Element in Constructivist Classrooms. California: Corwin Press.

Hernowo. 2007. Menjadi Guru yang Mau dan Mampu Mengajar yang Menyenangkan. Jakarta: MLC.

Joyce, B., Weil, M., \& Calhoun. 2011. Models of Teaching Model-Model Pengajaran. Edisi Kedelapan. Terjemahan oleh Achmad Fawaid dan Meilla Mirza.Yogyakarta: Pustaka Pelajar.

Kent, M., Gilbertson, D.D., \& Hunt, C.O. 1997. Fildwork in Geography Teaching: a review of the literature and approaches. Journal of Geography in Higher Education, 21(3): 313-332.

Khafid, S. 2007. Profil Guru Geografi yang Profesional dalam Membangun Siswa Berperilaku Konstruktivis. Jurnal Geografi dan Pengajarannya, 6(11): 580-592.

Kinniburg, J. 2010. A Constructivist Approach To Using GIS In The New Zealand Classroom. Journal New Zealand Geographer, 66: 74-84.

Matthews, J. A. \& Herbert, D. T. 2004. Unity in Geography. Dalam John A. Matthews and David T. Herbert. Unifying Geography Common Heritage, Shared Future. London: Routhedge.

Mustaji \& Sugiarso. 2005. Pembelajaran Berbasis Konstruktivistik: Penerapan dalam Pembelajaran Berbasis Masalah. Surabaya: Unesa University Press.

Mustaji. 2010a. Pengembangan Model Pembelajaran Berbasis Masalah dengan Pola Belajar Kolaborasi (Model PBMPK). Jurnal Pendidikan \& Pembelajaran,17(2): 187-200.

Mustaji. 2010b. Pendekatan Konstruktivistik Teori dan Penerapan dalam Pembelajaran Berbasis Masalah. Surabaya: Unesa University Press.

Mutohir, T. C. 2003. Wacana Pendidikan di Era Globalisasi. Surabaya: Unesa University Press.

Pawson, E., Fournier, E., Haigh, M., Muniz, O., Trafford, J., \& Vajoczki, S. 2006. Problem-based Learning in Geography:Towards a Critical Assessment of its Purposes, Benefits and Risks. Journal of Geography in Higher Education, 30(1): 103-116.

Prasad, A.H.H. 2013. Mengamati Fenomena Geografi. Cet. ke-1. Y ogyakarta: Digna Pustaka.

Saleh, R.I.S. 1996. Sumbangan Pendidikan Geografi dalam Pembentukan Manusia Berwawasan Kebangsaan Indonesia. Pidato pengukuhan guru besar dalam bidang pendidikan geografi Fakultas PIPS disampaikan di depan Rapat Senat Terbuka IKIP Yogyakarta, Sabtu, 14 Desember.

Sudaryono, L. 2006. Pengantar Geografi. Surabaya: Unesa Press.

Suharyono \& Amien, M. 2013. Pengantar Filsafat Geografi. Yogyakarta: Ombak.

Willis, J. \& Wright, K.E. 2000. A General Set of Prosedures for Constructivist Instructional Design: The New R2D2 Model. Educational Technology, March-April:5-20.

Zamroni. 2000. Metode Alternatif Belajar/Mengajar Ilmu Pengetahuan Sosial. Jakarta: Direktorat Pendidikan Menengah Umum, Depdiknas. 